\title{
Pirandello and the enigma of non-sense
}

When an idea is set to words, its identity varies and differentiates - something is either added or subtracted from the original. Every time we seek to incarnate our ideas, we exercise an act of translation - itself an original act which runs the risk of committing the original sin of betraying its purpose. The noted Italian dictum "traduttore-traditore" sits as witness to the fact. To set to words the Idea is to translate it, and to translate it is to risk betraying it, an act of tra-dire (to say in between) the original Word. The way we read Ovid's Metamorphoses, as a fable of constant translation, of ironic and tragic change of constant identity into new forms, parallels a reading of any text.

As an essential codified form, Art, like religion and law, reaches a point where it overcompensates, it becomes aggressive and appropriative. Ironically enough, Art then displaces its original intention and betrays its very purpose. When this occurs, man reflects and discovers that his very consciousness of the contradiction indicates that Art has assumed a conceptual mode of behavior, and as such, its original impulse to discipline and give form to change now collides with its demand to control and imprison reality. Caught in the contradiction, man is soon forced to explicate and can only do so by resorting to so-called absurd, paradoxical formulations, such as reformulating Art as that mode of expression that defines itself in terms of what it is not.

What constitutes the artistic element in modern Art is the discovery and enactment of its impossibility to be faithful to its original intent, for Art has in its own blood the seed to betray itself every time it expresses itself. The artistic crisis that invents the so-called "modern" man is the crisis of the word and its inability to make sense. When man does speak, he is poignantly aware of the word's nonsense and its own limitations - as Kierkegaard had already declared when he states: "But what is this unknown something with which Reason collides when inspired by its paradoxical passion?" (Philosophical Fragments, p. 49) 
Luigi Pirandello's works manifest this crisis. Pirandello seems to have perceived life in terms of the problem of translation, that because life presents itself to us as a metamorphic game, man in turn responds by adapting forms as techniques for grounding meaning. The mechanism employed is that of compensation, of adding or subtracting in order to reach some stable order. The word "nonsense" seems to me to be most appropriate to apply to Pirandello's art, for, as I would like to show, it is his coming to terms with the concept of the nonsense that gives his works their main thrust.

His major work, Sei Personaggi, was written and performed for the first time in 1921. Following four years of polemical criticism, Pirandello felt compelled to write his own apologia, entered as a "prefazione" to the fourth edition of the play in 1925. This Preface not only could be viewed as issuing a manifesto for modern art, but more specifically, can be taken as a connotative statement regarding the specific nature of the poetic art. The more one reads this piece, the more one realizes how its poetic function far outstrips the apologetic service that was originally intended. When I term the Preface a connotative statement, I mean that it, too, like the text it claims to defend, is a "poetic" act; the Preface is a mimetic gesture that parallels the nature and function of the play it aims to redeem. In other words, the reconstituting role of explaining the play is but an imitation of what constitutes the subject matter of Six Characters in Search of an Author. In the attempt to understand the critical discourse sustaining the work of Six Characters, therefore, we will often look to the Preface as a reflective statement that imitates and reenacts the makeup of the play itself.

But before we attempt our critical act, let us briefly recall the play in a summarized version. We are told that we are facing an empty stage onto which a group of actors will enter and on which will begin a rehearsal with their director of a Pirandello play, Il ginoco delle parti (Rules of the Game). Shortly thereafter the rehearsal is interrupted by a family in mourning - a Father, Mother, a grown Daughter and Son, and two young children. These are six characters: fictions of the imagination of an author who has refused to write their story. They now seek another author so that their drama may be realized. From here the play unfolds, as Francis Ferguson suggests, on several levels of make-believe, or levels of discourse. The plot develops, as we recall, around the relationship which is born between the fictional characters and the living actors.

Staged as an impromptu performance, the play represents its very intention to be, as the subtitle declares, a "Comedy in the 
Making." What ensues is essentially a staging and an acting out of what ultimately is the basic theme underlying the Pirandellian poetics, namely the conflict between vital life forces and conventional forces devised by man. The first act is taken up by the conflict between the characters and the actors, who each in their own way, aim to establish their own identity. Within this theoretical discussion, the characters engage in another conflict among themselves in their attempt to sort out the details of their own story.

The Manager, having been persuaded by the theatrical plausibility of their "story," agrees to try it out, and the second act is the attempt to reenact the scene in Madama Pace's dress shop when the Father goes to visit the Mother and is unknowingly introduced to his own stepdaughter, to the shock and horror of the Mother who is present at the event but refuses to participate in order to protect the element of the private and keep the feeling of disgrace shielded. The director, who must accept the fact that the scene is there to be represented, nonetheless must compromise the text's intention if the theater is to physically survive; he must further the necessary betrayal by Judas if Christ's nature is to remain authentic.

The last act dramatizes a garden scene in which the Son, disdainful of having been abandoned, now refuses completely to participate, intent on respecting the author's will that the shameful acts of their story be left untold. The play comes to a close as the Son relates his running to the fountain where he finds the Young Boy staring into the fountain at the drowned body of the Baby Girl. Suddenly a shot is heard, and the melodramatic scene ends with the suspenseful question regarding the reality of the shot: "Pretense? Reality? To hell with it all," shouts out the Manager in disgust. "Never in my life has such a thing happened to me. I've lost a whole day over these people, a whole day!" And the curtain falls.

I have chosen Six Characters because, more than any other work by Pirandello, this one seems to me to incarnate the very problem the work seeks in some ways to resolve. The central issue of the play, or, let us say, the intent or the direction towards which the energies of the play are directed, is the dramatization of an "experience" that is freely determined to become its own subject of inquiry. The experience, as we know, is the experience of creativity, what Pirandello defines as "a nimble little maidservant" at the service of Art - Fantasia.

Now I would like to treat this "experience" as a space, itself a stage where the gratuitous presence of an "author" is encountered. The encounter is accidental, yet the fact that it does occur is 
necessary. Fantasy presents itself as an interruptive element, an accidental presence, just like the Six Characters themselves interrupt accidentally the everyday business of the Actors. And the Actors, who, since they are annoyed by the encounter at first must come to terms with it, whether by giving it a chance or refusing it, also represent the "author" in this space. Pirandello ponders over this very question when, in his Preface, he asks, "What author will be able to say how and why a character is born in his fantasy? ... I can only say that, without having made any effort to seek them [characters] out, I found, before me, alive - you could touch them and even hear them breathe - the six characters now seen on the stage. And they stayed there in my presence, each with his secret torment and all bound together by the one common original and mutual entanglement of their affairs, while I had them enter the world of art, constructing from their persons, their passions, and their adventures a novel, a drama, or at least a story. Born alive, they wished to live." (364)

The passage is most illuminating for what it alludes to more than for what it declares. What it declares is the presence of a gratuitous image, but unlike other images brought to him by the Fantasia, this one is most aggressive in its defiant way of being valueless - empty of significant meaning, as Pirandello so clearly claims: "Now, however much I sought, I did not succeed in uncovering this meaning (senso) in the six characters. And I conclude, therefore, that it was no use making them live." (365)

We must also add that in the paragraph before his statement, Pirandello places himself in opposition to what he terms "symbolic art," a mode which restricts meaning. Unlike this type of art, which, as he says, "starts from a concept, and from a concept which creates or tries to create for itself an image," his art, on the other hand, does the reverse, it "seeks in the image - which must remain alive and free throughout - a meaning to give it value" (un senso che gli dia valore) (365).

Six Characters in Search of an Author, therefore, is meant to enact the very problem concerning the giving of meaning to an image, rather than forming an image based on an idea or concept. Hence, the image with which Pirandello is faced is absent of meaning, or better, to use the Italian word, the image lacks a senso. The image, therefore, presents itself neutrally as non-sense. But, as we all know, it is precisely the absence of meaning, this non-sense, which becomes demonically obsessive, and will require a response, the necessary response that turns out to be the subject matter that produces the play - the "highly strange fact of an author who refuses to let some of his characters live though they have been born in his fantasy, and the fact that those characters, having by 
now life in their veins, do not resign themselves to remaining excluded from the world of art.... And so let them go where dramatic characters do go to have life: on a stage. And let us see what will happen." (366)

Confronting a non-sense image, however, means that once it is confronted as "something" it then becomes indeed "something" to be conceived. For instance, before the Existentialists made it a vogue to talk about "Nothing," Bergson pointed out in his Creative Evolution that the category of the negative is an invention of human language, because in Nature there are no negatives, everything being simply what it is. He then goes on to suggest that when Man confronts the idea of "Nothing" he can do this only by conceiving of Something. In other words, an image of Nothing paradoxically must involve an image of something.

The reference to Bergson is important because the shift from Nothing to Something is analogous to the shift in Pirandello from non-sense to nonsense. Pirandello, like a Freudian psychoanalyst, puts himself, as well as his readers, in the position to having to respond then to the interpretation of the image "non-sense" as nonsense. The concept of nonsense, like the apparent nonsensical dream of a patient, cannot in this case, be dismissed in a naturalistic or positivistic sense, as when we refer to something as being sheer nonsense. On the contrary the element of nonsense acquires a "transcendental" value, it standing for what, in fact, it is not. To translate this idea for the theater, especially the way Pirandello conceives it, would be to say that what Pirandello does is to dramatize the shift from the "empty" stage to the "emptiness" on the stage - from the image to the concept.

Confronting an image therefore that is inviting more for the fact that it possesses "negative" rather than positive meaning is facing fundamentally the problem of having to interpret "emptiness" as a symbolic meaning in terms of what it is not. An image like the empty stage that faces us as we enter the theater to experience Six Characters offers us the license to examine that reality, and not feel the conventional constraint imposed by a "meaningful image" whose secrecy or privacy can only be experienced by metaphorically peeping at the experience. In fact, as one critic (Robert Brustein) puts it, Pirandello, "having scourged the peeping and prying of the social community, is now attacking the community's peep-hole pastime, the theater." By tearing down the imaginary wall that traditionally formed the boundary separating the stage (Art) from the audience (Life), Pirandello succeeds not only in inverting the realistic convention of treating the stage as something other than a stage, but more significantly he manages to seriously subvert the very mimetic mode of representation. 
The idea of dismantling the artifacts and the techniques that give the stage the illusion of being the "reality" out there means that the audience, the reader, need not enter the world of fiction fictitiously by wearing a mask of the willing suspension of disbelief. To have the stage treated as a stage is to experience the ambiguity of a sign which is and a sign which means. The duality reality/ illusion collapses, the dichotomy literal/metaphorical is combined.

The effect, as we all know, is confusing, but I would suggest that this confusion is Pirandello's fortunate mistake. In other words, the common debates regarding the dominant Pirandellian themes: Art-Life, Illusion-Reality, Truth-Appearance, or whatever other antithetical combination we might have, should be read as hyphenated categories rather than slashed categories. The Pirandellian world is not schizophrenic but rather neurotic: it is an amorphous space in which black and white breathe and are sustained by a gray atmosphere. Experiencing a Pirandellian work is to participate in a neurotic experience, from Pirandello himself, to his characters, his actors, his audience, down to ourselves. The polemic is always posed antithetically, never synthesized. The polemic oscillates, sliding in and out of the polarized categories. The play-within-a-play pattern, an important technique for Pirandello, serves to blur the boundaries between fiction and reality, between text and the pretext, between actors and audience. The pattern manifests an interrogative tone, an interaction of forces that defy resolution.

It could be said that one finds oneself sliding in and out of these categories when one approaches the play of Six Characters. For example, we (Reality) decide to go and see the play Six Characters (Fiction) only to enter and discover that a group of actors on stage are only rehearsing (Reality-doing their job), when they are interrupted by a group of characters whose reality (Fiction) is persuasive enough to convince them to perform it. When we likewise have been pulled into their fiction, a shot is heard, the curtain drops, and suddenly we reenter the world we left before we came to the theater (Reality). The immediate reaction is one of being lost, a mode of thinking that takes up what Wittgenstein called the form of philosophical inquiry expressed in "I don't know my way about." (Philosophical Investigations)

The world we perceive no longer is expressed by the Shakespearean stage metaphor whereon all act out their roles. For Pirandello the stage is still a stage but with one added difference. The stage is there not so much to provide us with a space to play our roles but with a space to play our games. The stage metaphor slides into and becomes the game metaphor, a fact not so surprising when we 
recall that Pirandello chose his play Giuoco delle parti (1918) (The Rules of the (Game) as the play that the Actors are there to rehease before they are interrupted by the Six Characters. In other words this earlier play could be considered the sub-text of Six Characters in Search of an Author, the rehearsal of one's part, not one's role, in the game of life.

The difference between the stage metaphor and the game metaphor is the difference between the actor and the character. To act out one's life according to the stage metaphor is to understand one's self in terms of one's role - namely, to carry out the directions pre-established and written in a "script," precisely the kind of behavior the actors engage in when faced with this "new" case of having to represent the Six Characters. The "script" that the manager asks the Characters to provide in order to legitimize their claim is the sustaining element for role-playing. On the other hand, to act out one's life according to the game metaphor is to understand one's self in terms of the "part," or better, "performance" one gives. While the "role" is essentially determined by the "script," and is therefore mechanical, the "performance" exists to interpret the role, and is therefore organic.

Rehearsal, for the Actors as well as the Characters, takes place only because it is the role which is in question. The role places limits on what may be done, but more importantly, it calls for interpretation. Hence, an important distinction between the role and the "performance" is that the latter must always manifest self-criticism, experimentation, and improvisation every time it is acted out. For the "performance" there is no script, and for that matter, there is no "performance" per se but only rehearsals. This is what the Six Characters are asking the Actors to understand. For Pirandello the stage of life is present not simply for acting out one's role but for improvising our "performances"; and we, like the Six Characters, continuously argue about how the play should be put on, i.e., interpreted.

The tension which is present throughout the play is, as I see it, the conflict present in all of us between stage playing and game playing, that is, that part of us which is unaware of our roles and that part of us which is aware and therefore criticizes our playing of it and the role itself.

These themes seem to me to be the main pillars sustaining Pirandello's Baroque structure, those very same columns which in a Baroque building are constantly tempting and inviting us to check and see if they're real or illusionary. And like Baroque illusions, Pirandello's art is most aggressive in its way of pulling us in asking us to verify our suspicions. Its authority is grounded 
in its ambiguity. So-called "reality" for Pirandello is literally an emblem - as its Greek etymology suggests - a kind of moveable ornament, a thing that is put on. The title that Pirandello gives to a collection of his plays which includes Six Characters in Search of an Author, that is, Maschere Nude (Naked Masks), is itself an enigmatic emblem of the kind of authority that ambiguity can claim. Does the concept expressed in "Naked Masks" mean that the mask is transparent and reveals the emptiness that lies behind it? Does it mean that the mask is opaque, thereby covering up the emptiness? Does it mean that the mask itself is colorless like the substance it represents? Moreover, does the title refer to a literal or a metaphorical reality, and more importantly, how are we to read it literally or symbolically? Like Kafka's parables which, as he writes "set out to say merely that the incomprehensible is incomprehensible, and we know that already," ("On Parables"), Pirandello's Naked Masks sets out to say that ambiguity is ambiguous, and that we already know, too.

Pirandello, like Kafka and so many other modern artists, sees his purpose in life in terms of literary mission, and because of it, like a religious mission, art consumes his life. Art is the expression of feeling revengeful, as Pirandello confesses, for having been born. But, as we all know, artistic obsession, like religious obsession, moves and continues to move forward for the simple but neurotic reason that in order to affirm one must deny. Tertullian's paradoxical statement concerning Christ's resurrection, "I believe it because it is absurd," is likewise the artist's credo when it comes to defending and justifying his religion. And it is this religion which has now become the theater's "raison d'être."

In traditional theater acting is rehearsed while in Pirandello rehearsal is acted. In Pirandello the lines are blurred between audience and stage, between author and director, between director and actor. In Pirandello the actor off-stage (the character) is onstage and hence his identity is confused. In traditional theater any discussion of what makes theater must be gleaned from and after a play, whereas in Pirandello the discussion of what is theater is the play. Most critics from Croce to the most recent on Pirandello inevitably feel compelled to make some critical reference to his everpresent "cerebral" aspects, and it is his cerebral quality which shocked the realist tradition of the theater.

I see Pirandello as basically a Platonic theoretician (his essay on Humorism is ample evidence), and it is because he is a Platonist and a theoretician that he has made a decisive mark in the field of drama. One critic, for example, points out: "The playwrights who follow Pirandello are frequently better artists, but none would 
have been the same without him: Pirandello's influence on the drama of the twentieth century is immeasurable." Showing that he, in some unique way, influenced leading artists such as Sartre, Camus, Becket, Ionesco, O'Neill, Genet, and others, this same critic concludes: "The extent of even this partial list of influences marks Pirandello as the most seminal dramatist of our time; and it may be that he will ultimately be remembered more as a great theoretician than as a great practitioner." (R. Brustein)

My own theory is that Pirandello's art is a search to dramatize a fundamental theme, and any discourse which deals with the nature of the fundamental is by definition Platonic. The search for an Author is, fundamentally, the search for Authority, and all Authority has its Author in metaphysics.

For an Aristotelian, the problem always appears to be one of strategy, as illustrated best, perhaps, in the employment of rhetoric, the technical strategy used in order to persuade. And there is the rub - the how and why of persuasion. Is persuasion meant to convert (L. cum-vertere $=$ turn completely) or to convince (L. Cum-vincere = conquer completely)? The former is a matter of religion, the latter is a matter of politics. In the former case, the problem is one of how to be faithful to what is to be represented, whereas in the latter it is one of how to form a trust-worthy representation. The difference is more explicit in the Italian words, "fede" (faith) and "fiducia" (confidence). The Aristotelian technique leans more towards persuasion as a means to convince. (In reference to the theater itself, it is interesting to recall that Francis Bacon in Novum Organum devised the class of the so-called "Idols of the Theater" as an attack on Aristotle for having created a means of promoting uncritical acceptance of Authority). The element of deception, comparable to the third dimension of perspective depth - is the critical factor for the effective mode.

Pirandello's technique aims to convert rather than convince, and if art could be seen as a converting technique, it might then be suggested that Pirandello's Six Characters presents itself as a lightning bolt, a force that induces a kind of immediate conversion, reminiscent of a Pauline conversion, as opposed to the long and mediated one of Augustine. This conversion is not cathartic, however, and its effect is not pleasing. It is a conversion to the void, a conversion to the idea of relativism.

The characters in Six Characters, like the protagonist of the novel, Il fu Mattia Pascal, are good illustrations of heroes who, because they resist to live the parts demanded by their roles, end up reverting to a fabulous mode of behavior. Their desire for immediacy and wholeness is nothing but the desire to live literature. But to be 
conscious of this fact is to acknowledge that such in itself is a fiction, for to take it otherwise would be to live literature literally, and we all realize, like Paolo and Francesca, that to live literature is an insane adventure.

But madness is just another vehicle for Pirandello to lead us to the more central issue of how to relate art to life. Madness is just an effective technique used to bring us to the understanding that ultimately there are no differences. Of course, Pirandello's play is still a play. The point is that we are forced to interpret what in "real" life corresponds to that "vision" which causes a character to go mad. I interpret this vision to be an insight, an inner acknowledgement of reality to be an enigmatic emblem.

Looking through a screen one views an enigmatic image authorless and void of personality. The image is that of the same Fantasia that obsessed Pirandello to write and defend Six Characters, and is the image that forms the nature of character embodied in the Six Characters themselves. From the image we derive the concept of ambiguity, the stage of being in the middle between all dualities. Being the uprooted Sicilian that he was, Pirandello managed to convey the modern preoccupation with belonging to the unique category of the "neither-both." In the wider sense we know that this preoccupation is the occupation of the artist. Occupying the space of the "neither-both" essentially means holding the position of a translator, a middle job, expressed more adequately if we use its corresponding term in Italian, "interprete." As an occupation, the job is that of simultaneously translating and interpreting. Translation must by nature tend towards transformation, a fact that only adds the more serious risk of betraying which we have talked about before. Pirandello takes this risk and dramatizes it, and in doing so, points to the risk involved whenever we venture to express ourselves creatively - itself the most ambiguous act we can undertake.

If we have learned anything from Pirandello, it must be that the last lines of the play, pronounced by the Manager, are a clear expression of "nonsense" when not undrestood in their ambiguous meaning. "Pretense? Reality? To hell with it all! Never in all my life has such a thing happened to me. I've lost a whole day over these people, a whole day!" The manager has seen, but with no insight. Hence, the initial image that for Pirandello lacked specific meaning, has by now been transformed to be taken to be meaningless by the Actors, in order that we may understand that at its origin it was its ambiguous meaning that forced it to be refused by both author and actors, and consequently forced it to be acknowledged. 
To conclude, Pirandello's art speaks for the irony of Art itself, that is, that the creative gesture whose purpose it is to formulate permanent forms, simultaneously also reveals its failure to accomplish its intent. Art, like translation, cannot help but undermine and betray the very thing it sets out to accomplish. However, by a curious inversion of the logical process, admitting one's failure allows one to speak about art as an interpretative mechanism that provides man a means to deal with the ambiguous tensions with which he is destined to live. Art is always that "third" element that mediates all the dialectical, binary forces we have been able to detect in life. Like language itself, Art is the fictive element that man has contrived in order to interact with reality, but perhaps more significantly, it stands as man's symbolic gesture to center his attention on action that has gone wrong. Viewed from the Pirandellian perspective man can be distinguished to be the incredible animal that he is not so much because he can legislate the truth, but because he can adjudicate the process for reaching it.

Pirandello, therefore, stages the dramatic issue of the theater itself. In Pirandello's hands the theater asks the questions of how we know and how we can value what we know but, more literally, it asks how man can act in terms of what we value. The theater explicitly places the human actor at the center of the "stage" and indeed requires of him to ask in what manner he may properly be called an "actor." The theater, unlike any other genre, preaches the very fact that Man is an actor, an agent whose very nature is to perform (L. actuare) by giving direction. The Six Characters, the Actors, as well as Pirandello himself undertake to carry out their acts not as a reflexive response like withdrawing one's hand from a fire, but rather as an acting upon, as when one extinguishes a threatening fire. As an "actor," therefore, Pirandello sees his role as a theater agent who finds it necessary to stage the problem of enacting the crucial concept that at the root of all action there lies an ethical problem, or as Kenneth Burke would put it: "Action involves character, which involes choice; and the form of choice attains its perfection in the distinction between Yes and No (between thou shalt and thou shalt not)." Though the concept of sheer "motion" is non-ethical, "action" implies the ethical (the human personality).

In his Six Characters in Search of an Author Pirandello can be said to be in search of a "character" himself, that is, a system of values for action. As a "comedy in the making," Six Characters is clearly not a tragedy, wherein a closed structural meaning of the universe has been challenged and no substitute order of values has been replaced, nor is it clearly a comedy wherein the tensions are brought to a resolution. The play is humoristic - in the most 
Pirandellian sense of the word, an antithetical combination of the tragic and comic. In this sense the play presents itself like an interrupted sentence, an active verb without its full predication, awaiting a redeemer to bring it to fulfillment.

Throughout his philosophic occupation, Wittgenstein on occasion would make reference to a favorite passage of his borrowed from St. Augustine's Confession (I,IV) that states: "What you wretch, so you want to avoid talking nonsense? Talk some nonsense, it makes no difference!" Faced with the same passage, the proud, stubborn Sicilian would have responded: "Talk some nonsense, it does make a difference!"

Yale University 